\title{
TNFSF18 Gene
}

National Cancer Institute

\section{Source}

National Cancer Institute. TNFSF18 Gene. NCI Thesaurus. Code C143026.

This gene plays a role in the modulation of $\mathrm{T}$-cell activation and proliferation. 